\title{
DEVELOPING MIND MAPPING TECHNIQUE IN TEACHING WRITING DESCRIPTIVE TEXT GRADE XI AT SMAN 1 SIBORONGBORONG
}

\author{
*Elsa Ompusunggu \\ **Elia Masa Gintings \\ ***Yeni Elita
}

\begin{abstract}
Ompusunggu, Elsa. Registration Number: 2132121012. Developing Mind Mapping Technique In Teaching Writing Descriptive Text Grade Xi At SMAN 1 Siborongborong. A Thesis, English and Literature Department, Faculty of Language and Arts, State University of Medan, 2018.

This research was aimed at develops technique as media in teaching writing descriptive texts. This study was conducted using R \& D method by Borg \& Gall (2003). The research took place at SMAN 1 Siborongborong. The sample consisted of class 11-XI. The evaluators of the media were two experts. The instruments employed in this study were questionnaire, interview, and test. The findings of the study were the quality of the developed technique as media viewed from the experts is very good $(88 \%)$. The final product of the technique as media was assessed by gave questionnaires to the students to know the students' responses about the media. Most students gave positive responses. Most students said that the media was interesting and it could help them to understand descriptive texts easily. The results of the test show that the technique as media improved their ability in writing descriptive texts (average score: 80,12 ). The scoring system was based on five aspects; namely content, organization, vocabulary, language use, mechanics. Therefore, the writer suggests that English teachers develop technique as one of the creative way to improve the students' ability in writing descriptive texts.
\end{abstract}

Keywords: Descriptive texts, pictures, writing.

*Graduate

**Lecturer 


\section{INTRODUCTION}

\section{Background of the Study}

The mind mapping technique is one of the teachers' techniques in teaching. Not only Mind Maps show facts, but also show the overall structure of a subject and the relative importance of individual parts of it. It helps students to associate ideas, think creatively, and make connections that might not otherwise make (Buzan, 2010). As Alamsyah (2009) explained that mind maps work well as their visual design enables students to see the relationship between ideas, and encourages them to group certain ideas together as they proceed. The mind mapping technique can be used to explore almost any topics in writing and also used in every kind of writing such as: narrative, descriptive, recount, persuasive, argumentative, essay etc. students can improve their ideas and lend themselves to discussing ideas in groups. According to Murley (2007), mind mapping can maximize brain's ability in associating number with visual qualities (space, image, color) and as the result the memory will be able to store more fact.

A mind-map is made based on radiant thinking, a concept which describes how the human brain processes various ideas and information that are associated to each other through relationship hooks (Buzan \& Buzan in Budd, 2003; Murley, 2007; Siriphanic \&Laohawiriyano, 2010; Al-Jarf, 2011).

Actually, there are many techniques to make teaching interesting, especially in teaching writing. in this part, the researcher will try to conduct Mind Mapping Technique in writing descriptive text. 


\section{REVIEW OF LITERATURE}

Writing is the expression of language that is used to convey and explain idea in form of letter or symbol to reader. It is also a tool and skill of writer to communicate information and ideas to readers in written form. Writing is the process of putting ideas down on paper to transform thoughts into word, to sharpen ideas, to form structure of the ideas into coherent organization (Ahlsen 2005: 4). According to Peha (2003: 89), writing combines process and product. The processes are presented with gathering ideas and comprehend words into sentences and products of writing contain the output of process in writing. Barnett (2008:9) says that writing is an expressive process. That is why the learners can express their ideas, feeling, emotion, estimation or opinion.

Based on the explanation and opinion above, it can be concluded that writing is an activity of expressing idea, feeling, emotion, estimation or opinion in written form. Through writing people give information to the readers about writer's thoughts and ideas which are organized in sentences

Flashcards are a kind of media which consist of cards printed with words and pictures that can be obtained by the teacher easily. The pictures are about $20 \mathrm{x}$ $23 \mathrm{~cm}$ in size. Flashcards are used in the classroom as teaching devices and can be used as components in stages of teaching writing. The pictures will be effective if they are used in the flashcards form (Gelfgren 2012: 5). The pictures in the flashcards form should be big enough, interesting and clear for students to be seen. According to Bowen (in Janah's 2013: 192), the pictures can make the students' imagination work for what they are expected to produce. 


\section{RESEARCH METHODOLOGY AND FINDINGS}

Methodology

Research and development method is the research method that is used to develop and validate educational product such as teaching method, teaching learning media, and teaching learning book (Borg \& Gall, 2003).R \& D has stages of educational research as following:

1) Gathering information and data, 2)Analyzing data, 3) Designing Media, 4) Validating, 5) Revising, 6) Revised- developing ( producingfinal products).

\section{Subject of the Research}

The subject of this research was the 11th grade students of SMAN 1 Sibiringborong consisted of 41 students.

\section{Technique of Analyzing the Data.}

Technique of data analysis that was used in this research was qualitative descriptive analysis. To analyze the data of the advisability of the product, the researcher gave questioners to media experts. These experts were the lecturers of State University of Medan and an English teacher of SMAN 1 Siborongborong. The questioners which are used are to determine the assessment and conception about the product. The questioners also were given to the students to know whether the media can improve their interest and ability in writing descriptive text.The data analysis technique used five categories of statements, namely: (5) 
Very Good, (4) Good, (3) Fair, (4) Less, and (5) Very Less. To analyze the data of questionnaire, the formula is:

$$
\mathrm{P}(\mathrm{s})=\mathrm{S} / \mathrm{N} \times \mathbf{1 0 0 \%}
$$

Where:

$\mathrm{P}(\mathrm{s})=$ the percentage of sub-variables

$\mathrm{S}=$ the total score of each sub-variables

$\mathrm{N}=$ the amount of maximum scores

Table 1: Interval assessment criteria

\begin{tabular}{|l|l|l|}
\hline No & Interval & Criteria \\
\hline 1 & $81 \% \leq$ score $\geq 100 \%$ & Excellent \\
\hline 2 & $61 \% \leq$ score $\geq 80 \%$ & Good \\
\hline 3 & $41 \% \leq$ score $\geq 60 \%$ & Fair \\
\hline 4 & $21 \% \leq$ score $\geq 40 \%$ & Less \\
\hline 5 & $0 \% \leq$ score $\geq 20 \%$ & Very less \\
\hline
\end{tabular}

(Kristiningrum in Supra Cipto, 2016: 8)

\section{FINDINGS}

From the table below, it shows the average score given by the experts is $88 \%$, so the assessment of the indicators is very good.

Tabel 2: The data of experts' validation to media based on the mind mapping technique

\begin{tabular}{|l|l|c|c|c|l|}
\hline \multirow{2}{*}{ No } & Item assessed & \multicolumn{2}{|c|}{ Expert } & \multirow{2}{*}{} & Criteria \\
\cline { 2 - 5 } 1. & $\begin{array}{l}\text { The selection of the } \\
\text { type and size of the } \\
\text { media }\end{array}$ & 5 & 5 & $\frac{10}{10} \times 100=100$ & Very Good \\
\hline 2. & $\begin{array}{l}\text { Ease to use the } \\
\text { media }\end{array}$ & 4 & 4 & $\frac{8}{10} \times 100=80$ & Good \\
\hline 3. & $\begin{array}{l}\text { The suitability of the } \\
\text { picture to description }\end{array}$ & 4 & 5 & $\frac{9}{10} \times 100=90$ & Very Good \\
\hline
\end{tabular}




\begin{tabular}{|l|l|c|c|c|l|}
\hline 4. & $\begin{array}{l}\text { The color } \\
\text { composition of } \\
\text { media }\end{array}$ & 4 & 5 & $\frac{9}{10} \times 100=90$ & Very Good \\
\hline 5. & $\begin{array}{l}\text { The suitability of the } \\
\text { text to the picture }\end{array}$ & 4 & 4 & $\frac{8}{10} \times 100=80$ & Good \\
\hline 6. & $\begin{array}{l}\text { The quality of things } \\
\text { that form media }\end{array}$ & 4 & 4 & $\frac{8}{10} \times 100=80$ & Good \\
\hline 7. & $\begin{array}{l}\text { The suitability of the } \\
\text { picture to topic that } \\
\text { learnt }\end{array}$ & 4 & 4 & $\frac{8}{10} \times 100=80$ & Good \\
\hline 8. & $\begin{array}{l}\text { The use of media in } \\
\text { teaching English } \\
\text { subject }\end{array}$ & 5 & 5 & $\frac{10}{10} \times 100=100$ & Very Good \\
\hline 9. & $\begin{array}{l}\text { The use of media in } \\
\text { teaching descriptive } \\
\text { text }\end{array}$ & 4 & 5 & $\frac{9}{10} \times 100=90$ & Very Good \\
\hline 10. & $\begin{array}{l}\text { The suitability of } \\
\text { media with the } \\
\text { curriculum that is } \\
\text { used. }\end{array}$ & 5 & 4 & $\frac{9}{10} \times 100=90$ & Very Good \\
\hline
\end{tabular}

\section{Chart 4.1 Experts' validation of Media}

The students' appraisal to media is shown in the table below:

\begin{tabular}{|l|l|c|c|}
\hline No & \multicolumn{1}{|c|}{ Appraisal } & Agree & Disagree \\
\hline 1. & $\begin{array}{l}\text { The media made me } \\
\text { be interested in } \\
\text { studying the topic }\end{array}$ & 41 & - \\
\hline 2. & $\begin{array}{l}\text { The media motivated } \\
\text { me to study the topic }\end{array}$ & 41 & 1 \\
\hline 3. & $\begin{array}{l}\text { By using the media, } \\
\text { I could understand } \\
\text { the topic easily }\end{array}$ & 40 & 1 \\
\hline 4. & $\begin{array}{l}\text { The media is useful } \\
\text { to improve my } \\
\text { ability in writing } \\
\text { descriptive text }\end{array}$ & 40 & \\
\hline 5 & $\begin{array}{l}\text { The material in the } \\
\text { media is easy to }\end{array}$ & 40 & \\
\hline
\end{tabular}




\begin{tabular}{|l|l|c|c|}
\hline & understand & & \\
\hline 6 & $\begin{array}{l}\text { The media made me } \\
\text { enjoy in studying } \\
\text { writing descriptive } \\
\text { text }\end{array}$ & & \\
\hline
\end{tabular}

Based on the information in the table above, it can be concluded that students' responses to media is positive.

CONCLUSION AND SUGGESTIONS

\section{Conclusion}

Referring to the discussion of the research in the previous chapter, the writer comes to this following conclusion:

1. Pictures which were developed in this study are suitable to be used for teaching writing descriptive, because of the data collected through interview, questionnaires, and test. The pictures are used as media to improve the students' descriptive text writing ability.

2. Pictures which were developed in this study is eligible to be used for teaching writing descriptive, because of the validation that given from the experts are very good. The media that is designed in the form of picture series into flashcards was very good. It can be seen from the responses given students through questionnaires, student learning outcomes improved significantly. Hence, pictures series in flashcards is effectively used in the learning process.

The Suggestions 
By considering the conclusion mentioned above, the writer suggests that picture series into flashcards is one of the media in teaching writing, especially in writing a descriptive text. The writer mentions some suggestions as follows:

1. Suggestions to other researchers

The researcher suggest to other researcher to develop picture in teaching writing descriptive text because the research proved that picture could stimulate the students to enrich their idea.

2. Suggestions to other teachers

The researcher suggest to English teacher to apply picture series as one of the alternative ways to improve students' ability in writing descriptive text.

\section{REFERENCES}

Abdullah M.A. Alhomaidan,2015. "The Effectiveness of Concept Mapping on Learning: A Study in a Saudi College-Level Context." American Journal of Educational Research, vol. 3, no. 8: 1010-1014. doi: 10.12691/education-38-10.

Azhary, 2011. Improving Students'achievement in Writing Descriptive Paragraph through Mind Mapping Technique in Junior High School. Medan, State University of Medan. 
Banjarnahor, 2012. Improving Students' achievement in Writing Descriptive Paragraph through Mind Mapping Technique in Junior High School. Medan, State University of Medan.

Buzan, B. 2006. Mind Mapping untuk Meningkatkan Kreatifitas. Jakarta: PT Gramedia Pustaka Utama.

Buzan, et al, 1995. The Procedure of Applying Mind Mapping Technique in Teaching Writing Descriptive Text. Jakarta: PT Gramedia Pustaka Utama.

Buzan, et al .2005. Buku Pintar Mind Map.Jakarta: Gramedia Pustaka Utama.

Buzan, et al .2006. Mind Mapping. IEngland: BBC Active.

Brown, H. Douglas. 2000. The Principle of Language Learning and Teaching. San Fransisco: Longman.

Brown, H.D. 2003. Language Assessment: Principles and Classroom Practices. San Fransisco: Longman.

Borg, W.R. and Gall, M.D. 1983. Educational Research. New York: Longman. 